\title{
SECONDARY ALTERATIONS IN TOTAL SERUM CALCIUM AFTER THE ADMINISTRATION OF GLUCOSE AND INSULIN
}

\author{
BY READ ELLSWORTH
}

(From the Medical Clinic of the Johns Hopkins Hospital, Baltimore)

(Received for publication July 1, 1929)

In studying the metabolism of a case of idiopathic hypoparathyroidism, in which the mechanism of the action of parathormone ${ }^{1}$ was under observation, Albright and Ellsworth (1) found that the initial state of high blood phosphorus, low blood calcium, and low calcium excretion in the urine was altered by administration of the hormone in the following way: immediately after injection, the phosphorus excretion in the urine rose, the blood phosphorus fell, the blood calcium rose and then the excretion of calcium in the urine increased. Similar alterations were observed by Albright, Bauer, Ropes and Aub (2). The immediate rise of phosphorus excretion in the urine suggested that perhaps the initial effect of parathormone was on the phosphorus; whereas, the effect hitherto so much stressed, namely, the rise in serum calcium, might be a secondary result. Certain workers have emphasized the changes in phosphorus metabolism in connection with parathormone (Greenwald and Gross (3)), though none except Albright, Bauer, Ropes and Aub (2) still go so far as to suggest that the primary effect might be on the phosphorus metabolism.

We have watched for some time to see if following the administration of parathormone there was, in the blood determinations, any lag of either $\mathrm{Ca}$ or $\mathrm{P}$ behind the other; but both in the case of hypoparathyroidism (1) and in normal individuals (unpublished) the first sample of blood to show a change in $\mathrm{P}$ concentration also showed a change in total $\mathrm{Ca}$. Even at hourly intervals the changes appeared to be synchronous.

${ }^{1}$ Preparation introduced by Collip and prepared by Eli Lilly and Company. 
It therefore seemed wise to study the behavior of the total blood $\mathrm{Ca}$ when the phosphorus was suddenly lowered by some other wellknown mechanism.

Some years ago Harrop and Benedict (4) demonstrated that the administration of glucose or glucose and insulin brought about a fall

TABLE 1

Blood sugar and chloride and serum calcium and inorganic phosphorus in patients 1 to 6 (Milligrams per $100 \mathrm{cc}$.)

\begin{tabular}{|c|c|c|c|c|c|}
\hline Patient & Constituent & Fasting . & 1 hour & 2 hours & 4 hours \\
\hline 1 & $\begin{array}{l}\text { Sugar } \\
\mathbf{P} \\
\mathrm{Ca}\end{array}$ & $\begin{array}{r}91 \\
4.9 \\
10.7\end{array}$ & $\begin{array}{r}114 \\
3.9 \\
11.3\end{array}$ & $\begin{array}{r}97 \\
4.2 \\
11.8\end{array}$ & $\begin{array}{r}100 \\
5.4 \\
10.6\end{array}$ \\
\hline 2 & $\begin{array}{l}\text { Sugar } \\
\mathbf{P} \\
\mathrm{Ca}\end{array}$ & $\begin{array}{r}80 \\
3.9 \\
11.2\end{array}$ & $\begin{array}{l}113 \\
3.0 \\
10.85\end{array}$ & $\begin{array}{r}111 \\
3.2 \\
12.3\end{array}$ & $\begin{array}{r}90 \\
4.5 \\
10.9\end{array}$ \\
\hline 3 & $\begin{array}{l}\text { Sugar } \\
\mathrm{P} \\
\mathrm{Ca} \\
\mathrm{Cl}\end{array}$ & $\begin{array}{c}82 \\
4.5 \\
9.0 \\
482\end{array}$ & $\begin{array}{r}140 \\
3.7 \\
9.6 \\
497\end{array}$ & $\begin{array}{c}80 \\
3.2 \\
9.8 \\
474\end{array}$ & $\begin{array}{c}80 \\
4.2 \\
9.8 \\
489\end{array}$ \\
\hline 4 & $\begin{array}{l}\text { Sugar } \\
\mathrm{P} \\
\mathrm{Ca} \\
\mathrm{Cl}\end{array}$ & $\begin{array}{r}91 \\
4.3 \\
8.9 \\
472\end{array}$ & $\begin{array}{c}178 \\
3.8 \\
8.75 \\
446\end{array}$ & $\begin{array}{c}86 \\
3.8 \\
9.25 \\
478\end{array}$ & $\begin{array}{c}98 \\
4.4 \\
9.05 \\
456\end{array}$ \\
\hline 5 & $\begin{array}{l}\text { Sugar } \\
\mathrm{P} \\
\mathrm{Ca}\end{array}$ & $\begin{array}{r}86 \\
5.6 \\
9.5\end{array}$ & $\begin{array}{c}51 \\
4.9 \\
10.25\end{array}$ & $\begin{array}{r}70 \\
4.0 \\
10.2\end{array}$ & $\begin{array}{r}62 \\
5.2 \\
10.6\end{array}$ \\
\hline 6 & $\begin{array}{l}\text { Sugar } \\
\mathrm{P} \\
\mathrm{Ca} \\
\mathrm{Cl}\end{array}$ & $\begin{array}{c}100 \\
4.2 \\
9.85 \\
467\end{array}$ & $\begin{array}{l}125 \\
3.5 \\
10.1 \\
47 \dot{6}\end{array}$ & $\begin{array}{c}60 \\
2.4 \\
10.45 \\
503\end{array}$ & $\begin{array}{c}40 \\
3.8 \\
9.8 \\
433\end{array}$ \\
\hline
\end{tabular}

of blood phosphorus. Since that time it has been shown that the decrease in blood phosphorus is due in all probability to the formation of hexose-phosphate. It was decided therefore to use glucose and insulin as the means of producing a sudden lowering of blood phosphorus. 
Accordingly six individuals were chosen who were, as far as could be determined, free from any disorder of calcium, phosphorus or glucose metabolism. Each patient after 14 hours fasting was given by mouth 50 grams of glucose in coffee and 50 units of insulin. Blood was taken just before the administration of insulin and at one, two and four hours thereafter. "The blood specimens were allowed to stand 20 to 30 minutes to ensure thorough clotting, then centrifuged and the

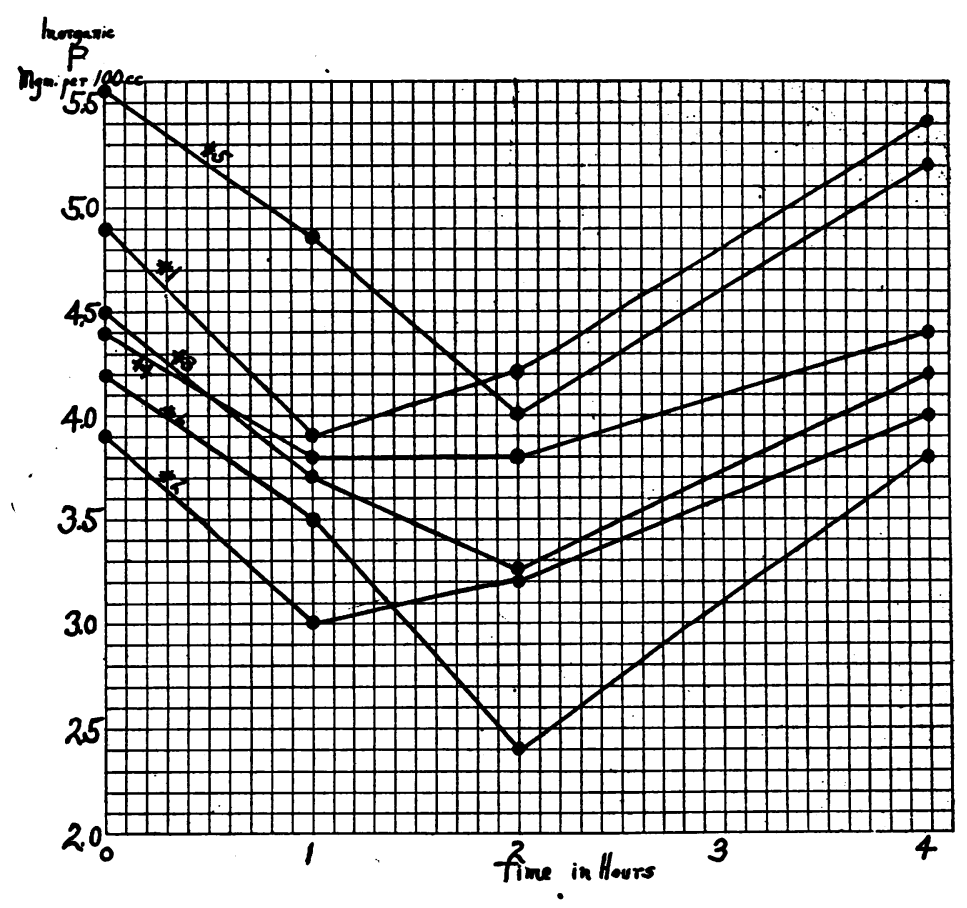

Chart 1. Composite Serum Inorganic Phosphorus Curves

Numbers over the curves indicate case numbers. Milligrams per $100 \mathrm{cc}$.

serum pipetted off. The determinations were started at once. The sugar estimations were made on whole blood, the phosphorus and total calcium on serum; the phosphorus was estimated by the method of Benedict and Theis (5) the calcium by the Fiske method described by Blackfan and Hamilton (6).

The alterations in the calcium and phosphorus are shown in table 1 and charts 1 to 3 . 


\section{OBSERVATIONS}

It will be seen, that in all cases the phosphorus was lowered at the end ${ }^{3}$ of one hour, remained low at the end of two hours, but usually had returned at the end of four hours toward the fasting level. The calcium was in four instances raised at the end of one hour and in all six raised at the end of two hours. At the end of four hours the

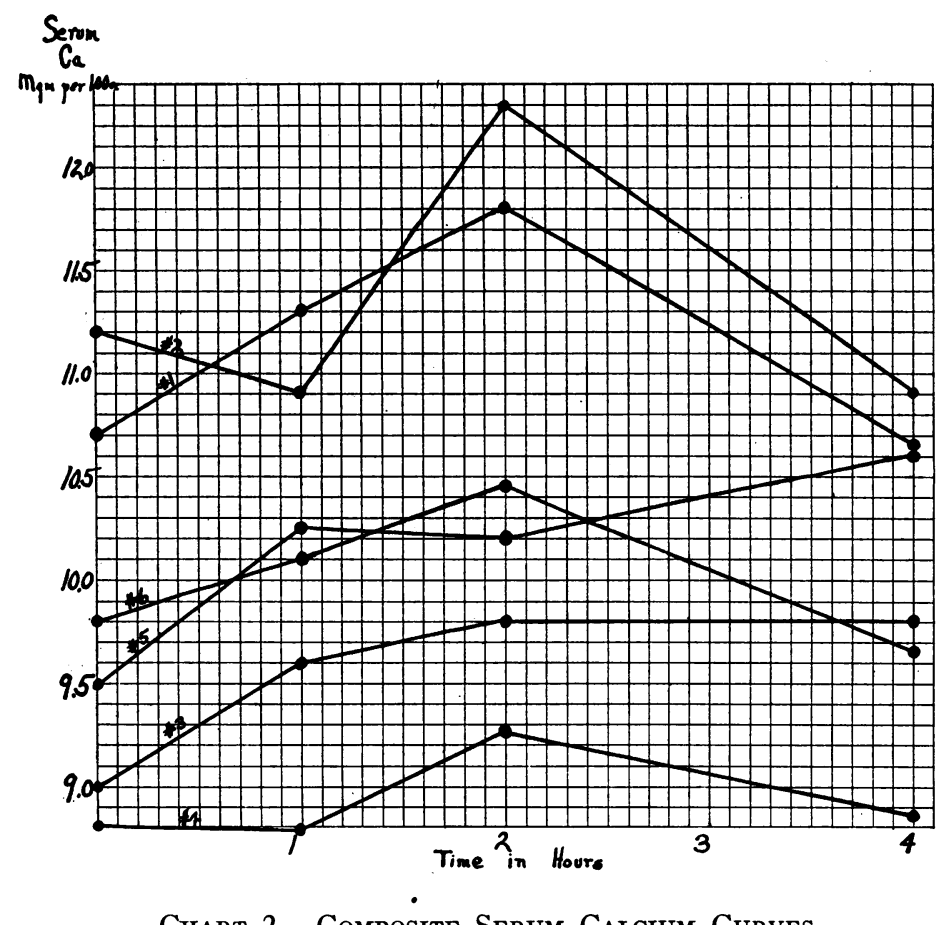

Chart 2. Composite Serum Calcium Curves

- Numbers over the curves indicate case numbers. Milligrams per $100 \mathrm{cc}$.

calcium in four of the six cases had fallen toward the control fasting level; in one instance, it was constant; in one it had risen still further. Two other patients, one (1A), a mild diabetic in the metabolism ward; the other (2A), suffering from general paresis, were studied in a slightly different manner. They received 25 units of insulin before their usual breakfast, which included in both cases fruit, toast and eggs and in addition 25 grams of glucose. The determinations were 


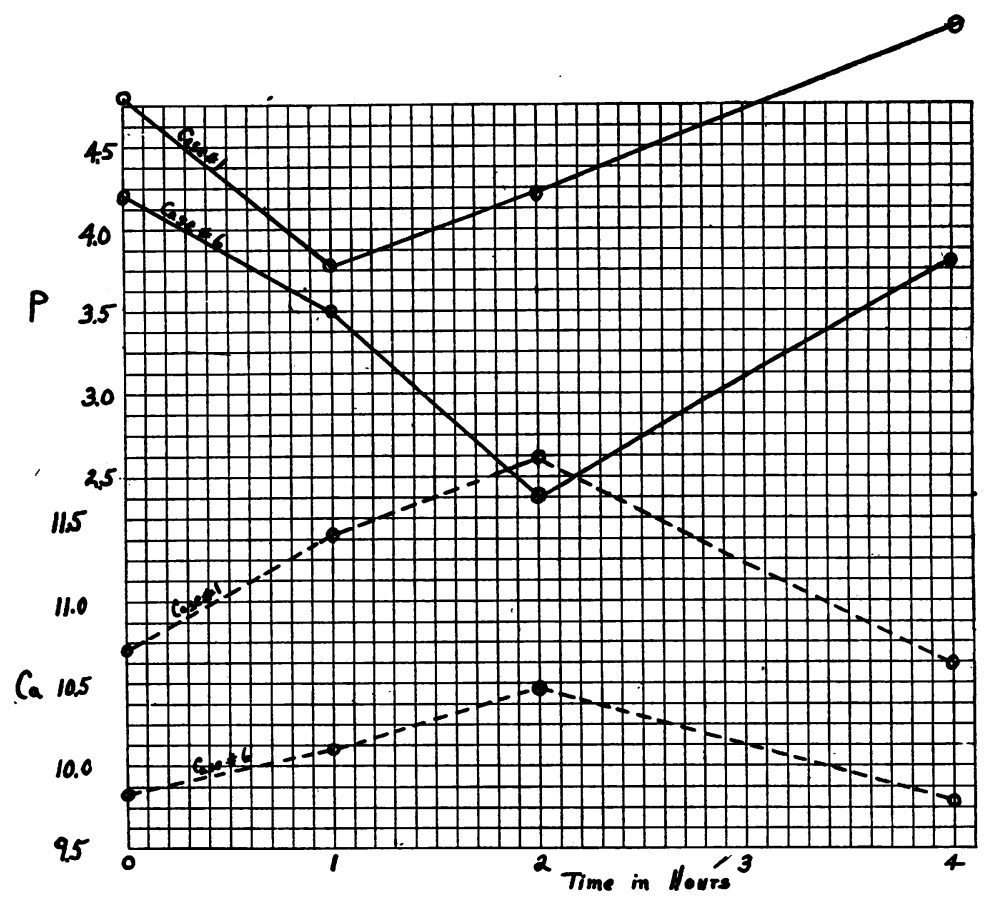

Chart 3. Sample Cases Serum Calcium and Inorganic Phosphorus Curves Milligrams per $100 \mathrm{cc}$.

TABLE 2

Blood sugar and serum calcium and inorganic phosphorus in patients $1 \mathrm{~A}$ and $2 \mathrm{~A}$ (Milligrams per 100 cc.)

\begin{tabular}{|c|c|c|c|c|c|c|}
\hline Patient & Constituent & Fasting & 1 hour & 2 hours & 3 hours & 5 hours \\
\hline $1 \mathrm{~A}$ & $\begin{array}{l}\text { Sugar } \\
\mathbf{P} \\
\mathrm{Ca}\end{array}$ & $\begin{array}{r}142 \\
6.6 \\
10.3\end{array}$ & $\begin{array}{r}138 \\
5.5 \\
10.9\end{array}$ & $\begin{array}{r}137 \\
5.3 \\
10.8\end{array}$ & $\begin{array}{r}100 \\
5.1 \\
10.3\end{array}$ & $\begin{array}{c}62 \\
5.1 \\
9.8\end{array}$ \\
\hline \multicolumn{2}{|c|}{ Refractive Index..... } & 1.3500 & 1.3508 & 1.3498 & $1: 3498$ & 1.3495 \\
\hline $2 \mathrm{~A}$ & $\begin{array}{l}\text { Sugar } \\
\mathbf{P} \\
\mathrm{Ca}\end{array}$ & $\begin{array}{r}104 \\
4.1 \\
9.7\end{array}$ & $\begin{array}{r}115 \\
3.6 \\
10.1\end{array}$ & $\begin{array}{l}73 \\
3.6 \\
9.9\end{array}$ & $\begin{array}{c}70 \\
3.5 \\
10.6\end{array}$ & $\begin{array}{r}3.7 \\
11.0\end{array}$ \\
\hline
\end{tabular}


carried out in the same manner as in the other six patients except that the blood specimens were obtained fasting and at one, two, three and five hours after breakfast. The results are shown in table 2 and chart 4. In both of these cases there was a fall of phosphorus and a rise of calcium. In case $2 \mathrm{~A}$ the rise of calcium was out of proportion to the fall of phosphorus. This may have been due in part to absorption of calcium received in the food. To remove this possibility the other six individuals received only glucose.

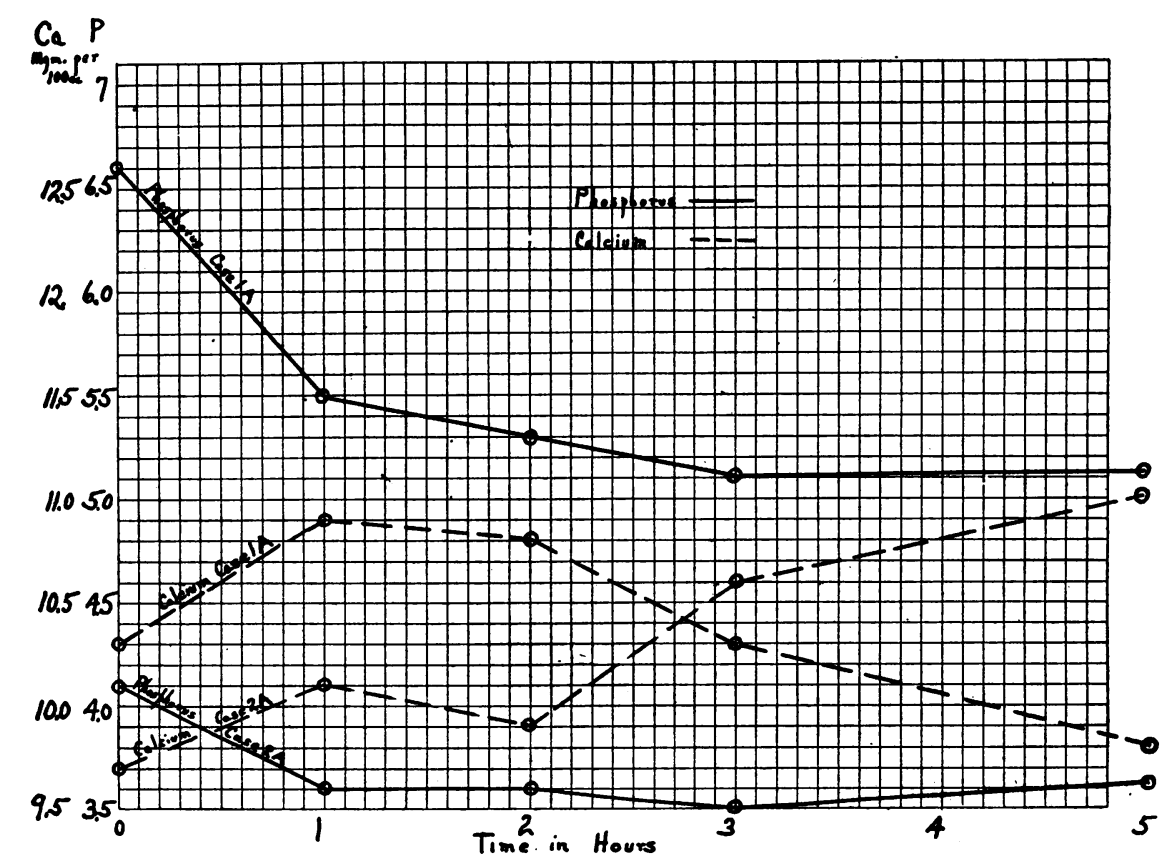

Chart 4. Five-hour Serum Calcium and Inorganic Phosphorus Curves Milligrams per $100 \mathrm{cc}$.

\section{DISCUSSION}

Observations upon eight individuals indicate that, when the blood phosphorus is lowered by the administration of glucose and insulin the total blood calcium rises. The increase in serum calcium under these circumstances has not, so far as I am aware, been observed previously. It does not seem probable that the increase in total blood calcium 
could be due to an anhydremia and decrease in blood volume, such as has been described by Drabkin and Edwards (7) and Drabkin and Shelkret (8) after the injection of insulin in animals; for the anhydraemia observed by them occurred only in association with hypoglycaemia, whereas it will be seen (tables 1 and 2) that, inasmuch as the patients in the present series received glucose as well as insulin, the rising calcium concentrations occurred in most instances during periods when the blood sugar was also increasing. The values of the blood chlorides (table 1) and of the refractive indices in case 1A (table 2) add still further evidence to show that there was not sufficient change in blood volume to account for the rise in the blood calcium.

It has previously been pointed out in some observations made upon the relative concentrations of blood calcium and blood phosphorus that the demonstrable rise in total blood calcium occurs almost synchronously with the demonstrable fall in blood phosphorus, and the present experiments show again the difficulties that are encountered when one attempts to determine by blood analyses which of these elements is the first to change. It is fairly well established, however, that one effect of the injection of glucose and insulin is the formation of hexose-phosphate and on this account it appears highly probable that in this series of observations the primary action of the insulin was upon the blood phosphate and that the rise in blood calcium occurred in all likelihood as a secondary phenomenon.

The explanation of the observed rise may be that, as the phosphorus is lowered in the serum saturated with $\mathrm{Ca}_{3}\left(\mathrm{PO}_{4}\right)_{2}$, more calcium and phosphate are mobilized from the bones so that the product of $\mathrm{Ca}$ ions times $\mathrm{PO}_{4}$ ions tends to be kept constant. As would be expected, if this were the explanation, it is seen that, in general, (table 1) the greater the fall of blood phosphorus, the greater the rise in blood calcium. Had we a satisfactory method for the determination, it would be interesting to know whether there was any alteration in the ratio of ionized and unionized calcium during the rise in total calcium.

The rapidity of the response of blood phosphorus and calcium to the administration of glucose and insulin suggests that tetanic seizures, associated with high blood phosphorus and low blood calcium, such as one encounters in parathyroid tetany, may be relieved by glucose 
and insulin. Moreover, it is possible that glucose and insulin may enhance the action of parathormone. Studies to determine these points are in progress.

\section{CONCLUSIONS}

1. The administration of glucose and insulin to six normal individuals, one diabetic patient and one patient with general paresis resulted in a prompt fall of phosphorus as shown formerly by Benedict and Harrop.

2. There was a definite tendency for the total serum calcium to rise.

3. The first rise in calcium was usually observed in the same hour as the first fall in phosphorus - the 'changes gave the appearance of being synchronous.

4. Both the phosphorus and calcium effects were seen to have disappeared usually at the end of four hours.

\section{BIBLIOGRAPHY}

1. Albright, F. and Ellsworth, R., J. Clin. Invest., 1929, vii, 183. Studies on the Physiology of the Parathyroid Glands. I. Calcium and Phosphorus Studies on a Case of Idiopathic Hypoparathyroidism.

2. Albright, F., Bauer, W., Ropes, M. and Aub, J. C., J. Clin. Invest., 1929, vii, 139. Studies in Calcium and Phosphorus Metabolism. IV. The Effects of the Parathyroid Hormone.

3. Greenwald, I. and Gross, J., J. Biol. Chem., 1926, lxviii, 325 . Effect of Long Continued Administration of Parathyroid Extract Upon the Excretion of Phosphorus and Calcium.

4. Harrop, G. A., and Benedict, E. M., J. Biol. Chem., 1924, lix, 683. The Participation of Inorganic Substances in Carbohydrate Metabolism.

5. Benedict, S. R. and Theis, R. J., J. Biol. Chem., 1924, lxi, 63. A Modification of the Molybdic Method for Determination of Inorganic Phosphorus in Serum.

6. Blackfan, K. D. and Hamilton, B., Johns Hopkins Hosp. Bull., 1927, xli, 322. A Study of the Inorganic Constituents of the Serum in Children with Acute Nephritis.

7. Drabkin, D. L. and Edwards, D. J., Am. J. Physiol., 1924, lxx, 273. The Production of Anhydremia with Insulin.

8. Drabkin, D. L. and Shilkret, H., Am. J. Physiol., 1927, Ixxxiii, 141. Insulin Anhydremia. 